\title{
SLANGA KEDAI KOPI: SATU ANALISIS SEMANTIK INKUISITIF
}

\section{MUHAMMAD ZAID BIN DAUD}

Fakulti Pengajian Bahasa dan Pengajian Komunikasi Universiti Malaysia Sarawak (UNIMAS) 94300 Kota Samarahan, Sarawak, Malaysia

\section{ABSTRAK}

Kajian makna slanga yang dijalankan oleh sarjana lepas kebanyakannya cukup berhenti di tahap semantik skrip dan semantik resonans sahaja. Oleh itu, kajian ini mengetengahkan penerokaan makna slanga berimplisit menggunakan pendekatan semantik inkuisitif (SI) oleh Nor Hashimah Jalaluddin (2014). Pengkaji cuba menginterpretasikan makna sebenar slanga ini dengan mengambil kira data - transkripsi perbualan di kedai kopi (KK), teori, kognitif, falsafah dan akal budi penuturnya untuk mencapai ke tahap SI. Hal ini demikian kerana tutur kata di kedai kopi ada yang menganggapnya sebagai suatu perbualan yang kosong bagi mengelakkan situasi yang hambar dan janggal di tempat tersebut. Namun, di dalam setiap tutur kata berikut wujudnya suatu makna yang implisit di dalam slanga yang dibicarakan oleh mereka. Kajian ini adalah berbentuk kualitatif dan telah mengaplikasikan teori semantik dengan kaedah inkuisitif. Analisis rangka rujuk silang (RRS) dilakukan terhadap slanga yang mempunyai kesiratan makna daripada 15 data terpilih berdasarkan transkripsi perbualan di KK ini. Gabungan RRS dengan maklumat budaya mendalam mampu menghasilkan penghuraian makna sebenar sesuatu slanga sehingga ke akal budi penuturnya. Dapatan kajian bagi slanga di KK ini antaranya terdiri daripada slanga kedai kopi yang berasosiasi dengan anggota tubuh badan, tumbuh-tumbuhan/buah-buahan, kelakuan manusia dan objek tidak hidup. Dalam masa yang sama penggunaan slanga ini mengandungi bahasa-bahasa figuratif yang masih mampu difahami namun, berselindung di sebalik makna eksplisitnya kerana ada topik yang dibualkan itu dianggap sulit. Oleh itu, perincian makna secara lebih saintifik terhadap tutur kata masyarakat di KK dapat dikemukakan daripada hanya membuat perspektif umum sahaja.

Kata kunci: slanga, makna implisit, transkripsi perbualan, semantik inkuisitif, rangka rujuk silang (RRS)

How to cite:

Muhammad Zaid Daud. (2017). Slanga kedai kopi: Satu analisis semantik inkuisitif (Unpublished final year project). Universiti Malaysia Sarawak, Kota Samarahan, Malaysia. 